\title{
nature
}

\section{Science and more for TB}

Traditional systems for developing drugs are failing spectacularly to deliver the goods in the fight against tuberculosis. Innovative public-private collaborations point the way forward.

$\mathrm{T}$ he diseases that afflict the developing world defy the imagination in their scale. One third of the world's population - 2 billion people — are infected with Mycobacterium tuberculosis, and 16 million have active tuberculosis (TB). Shockingly, TB hit an all-time high in 1999 with 8 million new cases - 95 per cent of them in developing countries - and 2 million deaths. The disease is spreading rapidly through Russia. The toll is set to rise; AIDS activates the dormant form of the disease, while multidrug resistance is spreading across the planet. Figures for malaria are similar, and AIDS is raging out of control throughout the developing world.

If global health is left to market forces, historians will remember this era as one in which humanity stood idly by while half the planet languished in sickness. Fortunately some enlightened individuals have realized this, and are driving forward new models for drug and vaccine discovery. The latest sign of this trend is the creation, at an international meeting last week in Cape Town, South Africa, of a Global Alliance for TB Drug Development, by a consortium of scientists, donor agencies and pharmaceutical companies (see page 692).

To be of practical use, any drug or vaccine must be cheap to produce and administer. Institutional innovation to overcome these obstacles is underway: as well as the public sector underwriting research to compensate for market failure, the less tangible goal of a tight coupling of scientists, regulators, donors and companies around shared objectives is also taking place. The alliance will need all the determination it can muster, and luck too.

Science alone is not enough. By coordinating research and taking into account the needs of those in the field, the alliance has a good chance of achieving its objective of a new TB drug by 2007. But also, as one delegate in Cape Town put it: "New drugs without effective control programmes = new resistance."
The time is right. The genome of M. tuberculosis is publicly available (http://www.sanger.ac.uk/Projects/M_tuberculosis), and a raft of technologies, such as DNA chips to identify genes involved in infection, are under development. Just as important as treatments for full-blown TB are drugs and diagnostics for the huge reservoir of carriers of the dormant form. Looking for genes activated during disease activation may help identify drug targets. Understanding how the dormant phase escapes drugs and the immune system is also a challenge.

Imaginative use of new technologies will be vital, because the venture's success hangs on cutting the costs of developing a new drug typically US $\$ 300$ to $\$ 500$ million - to $\$ 100$ million. Big drug companies will probably subsidize the venture by making their vast combinatorial-chemistry libraries and high-throughput screening technologies freely available. They will also be needed for getting bulk quantities of drugs distributed far and wide.

But the alliance may be going too far in defining its programme so as to win over the participation of the large drug companies. The latter's bureaucracies are ill-suited to rapid change and fast decisionmaking, and could defeat the alliance's ambition of being a lightweight structure. For innovation, flexibility and cost-cutting, the alliance would do better to shift its focus towards small pharmaceutical and biotechnology companies.

Drug companies need to make their drugs more affordable in developing countries. But developing countries must also play their part. The government of relatively rich South Africa is already equivocating over the known value of anti-AIDS drugs when one in four of its citizens is HIV-positive (see page 692). Even acknowledging the political difficulties, South Africa and other developing countries need reminding that the cost of business as usual will be much more than that of investing in the development of drugs and vaccines.

\section{Fossil smuggling unopposed}

Trading at fossil shows requires law enforcement.

A paleontology débâcle unfolding in the United States over a Chinese bird fossil from the early Cretaceous will probably go down as the classic example of the danger to science of amateurs dealing in smuggled specimens (see pages 689-690). The tortured tale of the fossil would be funny were it not for the fact that a potentially valuable slice of history may have been damaged.

The specimen was sold a year ago at a mineral and fossil show in Tucson, Arizona, to supporters of a small museum in Utah. Subsequently, the operator of the museum - who has no formal palaeontology training and little experience with peer-reviewed journals acted as the lead author of an article submitted to Nature and Science.

Despite the help of some well-meaning palaeontologists, the publishing attempt failed. Next, National Geographic magazine embarrassed itself by naively and hastily publishing an article - described as "sensationalistic, unsubstantiated tabloid journalism" by a leading paleontologist — sprinkled with dubious assertions.
But the real culprits are the fossil shows in the United States and Europe that provide a market for smuggled national treasures. Operators of the US shows say they try to make sure that dealers do not sell smuggled or illegal goods. The dealers have documents for the specimens that purport to permit their sale as scientific exchanges. But does anyone truly believe that someone can buy a transferable right to a scientific exchange in a cheap hotel room?

US federal authorities say that there are laws prohibiting trade in fossils smuggled from other nations, such as China. Scandalously, the law goes unenforced. At the Tucson show, state and city police were serving as security, even pawing through boxes of ivory from dubious sources for a specimen to take home. Hardly reassuring.

International agreements are needed to eliminate illicit trade in fossils, and scientists and museums should push for such pacts. But the power is already there to protect palaeontology from the illegal deals that have plagued the field for decades. It should be applied. 